\title{
HOW THE CONCEPTS OF FOLK MUSIC EMERGE
}

\section{The Terminology of Folk Music Festivals}

Primitive, vulgar, nationalistic, racial, colonialist, totalitarian. This is a small list of the strong adjectives that have been used in worldwide public discourse to describe folk music over the years. In spite of this, there are numerous popular music festivals around the world where the organisers do not hesitate to use the term folk music in the event name. What at first sight seems to be an innocent musical genre turns out to be a controversial phenomenon which conception and usage is essential to be investigated more closely.

The current article scrutinises the terminology of folk or traditional music that has been developed and is used in the context of folk music festivals. The research focus is on the author's fieldwork materials (interviews, sound and video recordings, a database of media responses, promotional materials) collected during the 2004-2018 period in the largest Finnish and Estonian folk music festivals: the Kaustinen Folk Music Festival in the county of Kaustinen in Central Ostrobothnia region in the the Western Finland, and the Viljandi Folk Music Festival in the town of Viljandi in the Southern Estonia. The main research interest is the process of the development of the folk music festival related ethnomusicological vocabulary. The goal of the research is to understand 
how folk music is talked about and how the relevant vocabulary has been shaped, influenced and reflected by the discourse of folk music festivals.

\section{Historical background of Estonian and Finnish folk music festivals}

Finland and Estonia have a long history of cultural contacts. The idea of a big public choir festival, that was popular all over the Europe, especially in Germany at the start of the 19th century, was adopted by the Finnish Fennoman movement through personal contacts with Estonia. The key persons were the Estonian cultural and public figures Johann Voldemar Jannsen and Lydia Koidula, who organised their first Estonian national song festival in Tartu in 1869. Inspired by the success of their relative nation, the Finns organised the first national song festival in Jyväskylä in 1884 under the leadership of Aksel August Granfelt. (Rantanen 2016: 19-21; Kuutma 1998.) As a result of these celebrations in the 19th and 2oth centuries in Estonia and Finland, also folk music, that was so far considered as a part of peasant culture, was recognized as an independent and valuable genre and was brought to public stages. (Rantanen 2013, 80.)

During the first half of the 2oth century, traditional cultures all over Europe were influenced by all forms of erstwhile popular music, for example polyphonic choir music, church and spiritual music, students' and workers' songs, composed music and so on. International cultural communications across Europe were considerably interactive. After the Second World War, official cultural contacts between Western and Eastern Europe stopped because of the complicated political climate of the Cold War. At this time free cooperation among folk musicians and ethnomusicologists on both sides of the Finnish gulf was also restricted. (Rüütel 2004: 14.)

In the 1960s worldwide interest in traditional cultures and lifestyles arose. At this time Western Europe was also conquered by the youth movement, which was influenced by social and cultural alienation and the identity crisis caused by rapid technical progress, industrialisation, political instability, increased migration and urbanisation. (lbid.) Even though this socio-cultural movement represented many of the traditional values of national revival of the 19th century, it also created an alternative to contemporary mass-mediated culture 
by encouraging widespread amateur participation in music performance and composition. (Hill 2014: 413.)

In this period of revival several large-scale popular festivals were born in Finland. Beside pop, rock and tango events, the Kaustinen Folk Music Festival was founded in 1968. The main goals of this event were re-establishing respect for the hitherto vanishing traditional music and rejuvenate a rural culture that had been decimated by rapid urbanisation. (Silvanto 2016: 10-11; Laitinen 1977 \& 1987.) A significant role in this process was played by traditional non-professional musicians (Finnish pelimanni). (Hill 2014: 413.)

The folk music revival had also other background factors. During the 1960s Finland experienced an American folk music fusion wave. It mainly consisted of songs with profound and/or protest lyrics accompanied by acoustic instruments, primarily guitars. This trend was the ground for the subsequent enthusiasm for folk music and contributed to the new rise of Finnish folk music. (Ramnarine 2003: 50; Наapoja 2017: 24.)

In the post Second World War Soviet Union all popular cultural movements, including the folk revival, were strictly controlled. During this period in Soviet Estonia the peaceful manifestation of ethnic identity was allowed mainly through participation in song festivals and folklore events. (Kuutma 1998; Šmidchens 2014.) Public folklore practice was under the control of censorship. Regulated folk music was represented by formalised village cappellas who performed archive material strictly from score. Traditional variation and natural improvisation on either text or melody were considered mistakes. The goal was to make the performance look like an authentic one. (See also 'iconicity' Peirce 2001; 'indexical icon' Turino 1999; Haapoja 2017: 158)

These folk-styled ensembles performed at important official celebrations and represented Soviet folklore on foreign trips. Their objective was to demonstrate the achievements of collective and assimilated Soviet culture through folkstyle adaptations and compositions of traditional music from all of the Soviet nations. Soviet cultural ideology was orientated towards mixing ethnic groups and creating a new quality of nation - Russian-speaking and collective-minded Soviet people. Folklore adaptations and stylized new creations fit better with this formalised conception. The curious thing was that these folklore ensembles were crowded because this was one of the very few officially accepted ways to 
practice Estonian ethnic culture. For people living behind the Iron Curtain the opportunity to have concert journey abroad was also motivating. (Rüütel 2004: 14.)

In 1960s only a few tradition-based music and dance groups were active in Estonia, for example Leigarid and Leegajus in Tallinn and Hellero in Tartu. Their priority was to keep old and traditional but at same time viable and sustainable heritage alive. They practiced learning songs, instrumental pieces and dances directly from elderly tradition carriers by listening and imitating, and mastered varying and improvising folk song melodies and words within the rules of the tradition. Through uncensored folklore these communities shared and kept alive the traditional skills and values of their ancestors. In this way they passively resisted the enforcement of a unified Soviet culture and russification. These communities were in opposition to the dominant and officially privileged folk music trend that followed the "Soviet in content, national in form" motto. Therefore, the public performances of authentic groups were limited to local and small events. (Ibid.)

In the 1980 traditional folklore festivals emerged in Estonia. These festivals were related to the re-independence movement. Among the first events were Viru Säru in 1986 in the Northern Estonian county of Virumaa and Viljandimaa Virred in 1989 in the Southern Estonian county of Viljandimaa. The first international folklore festival was Baltica in 1987. It was born through a collaboration of the Baltic States - Estonia, Latvia and Lithuania. Currently, there are around 20 regularly held folklore events in Estonia. These festivities were originally established by the ambition to function counterculturally to "Soviet culture", restore and strengthen local identity and resist both cultural mainstreams and mass culture. (Rüütel 2004: 15-16.)

The folklore movement in Estonia and in other Baltic countries was a part of the global folklore revival. On the one hand it was based on national ideals, the reinforcement and cultivation of local identities, preservation of continuity of cultural memory, and on the other hand, an appreciation of cultural diversity and respect for other peoples. (Rüütel 2004: 248.) Estonian music in general, and folk music in particular, became more intensely influenced by the international scene in the 1990s, when independent Estonia opened up to Western culture. One of 
the first and biggest local folk music breakthroughs was the Viljandi Folk Music Festival, born in 1993. (Kõmmus 2007: 198.)

The Finnish and Estonian folk music festival communities that practise traditional folk music today have their roots in the historical rural societies. They have preserved many traditional values, such as an appreciation of traditional, local folk culture, and at the same time adapted these traditions to the context of modern culture and music. In the case of folk and fusion music festivals we can speak about secondary tradition, where traditional culture is revived and presented in a form that is understandable to contemporary people. (Honko 1990: 99; Rüütel 2005: 18-19; Hill \& Bithell 2014: 12.)

Finnish contemporary folk musicians characteristically collaborate with foreign artists, search for source material in neighbouring countries, play traditional instruments from multiple cultures, speak of 'global folk music communities', and market their creations as 'world music from Finland'. Several multicultural contacts create new fusion musical identities that have an essential influence on local culture. (Hill 2007: 50.) As the borders between different genres are vague and musicians are constantly adopting new features, contemporary folk music (Finnish nykykansanmusiikki) has taken a significant position in the country's modern popular musical life. (Asplund 2006b: 523.) The approach of contemporary Estonian folk musicians to fusion music is more conservative. They combine cultural features from Western Europe, especially the Nordic countries, with a strong Finno-Ugric musical background, especially with the living musical heritage of the Southern Estonian Setu, and the Western Estonian Kihnu island traditions. (Rüütel 1999: 25.)

\section{Ambivalent definitions of folk and music}

The combination of the terms folk and music has fascinated (ethno)musicologist, folklore collectors and musicians since the end of the 18th century. (Herder 1778 1779) Conceptions related to folk music are constantly topical, especially in the context of the traditional and modern festivities. One of them - folk music festival - is nowadays a widespread cultural phenomenon. In historical scholarly discourse the festival commonly means a periodically recurrent and coordinated 
social occasion in which all members of a community, who are united by ethnic, linguistic, religious, historical bonds or a shared worldview, participate directly or indirectly. (Falassi 1987: 2; Kainulainen 2005: 65-67.)

In contemporary popular and urban contexts, a festival can be seen as a period of break from everyday routines and norms, which makes people more open to new ideas (Jordan 2016: 214). In the case of the festivals in the early 21st century, the practical economical ideas were adapted to this process as well. Nowadays the folk festivals and folk music as well has its place in the commerce, mass media and entertainment world. (Keegan-Phipps \& Winter 2014: 506-507.)

Folk music has been used both purposefully and inadvertently in the construction and in the denial of class, national and ethnic identities. Therefore, it continues to be a source of debates. At the root of the controversy lie questions about the identity and identification of folk and the delimitation of music, its repertoires, performances and sounds. In the historical academic ethnomusicological discussion in Europe, folk music was originally identified as peasant culture. The folklore of rural working people was idealised in contrast to the artistic production of urban and industrial societies. In the first half of the 2oth century the academic vocabulary of European musicologists distinguished between art music, popular music and folk music. Traditional music was generally used as a synonym of folk music. (Pegg 2001: 64-67; Livingston 1999: 69; Hill \& Bithell 2014: 19-24; Haapoja 2017: 17-18.)

The International Folk Music Council (IFMC), founded in 1947, incorporated to a definition of folk music English folksong collector Cecil Sharp's three conservative criteria - continuity, variation and selection - and the notions of rural tradition and anonymous oral transmission. The councils' concept embraced only music that had evolved within a community and was uninfluenced by popular and art music. (JIFMC 1955: 23; Sharp 1907; Karpeles 1967.)

In the course of time folk music became too narrow to describe the real music of communities and societies. From the 1960s, North American music research increasingly extended the meaning of folk music to include the music of different, and not only ethnic, communities. (Nettl 2010.) "Who is the folk?" became a central question (Dundes 1980). In response to criticism about the ethnically restricted and ethically outdated concept of folk, the International Folk Music 
Council changed its name to the International Council for Traditional Music (ICTM) in 1981 (JIFMC 1955, ICTM 2019).

In the 1960s anthropologists and ethnomusicologists emphasized that music should be studied in the context of its culture and the research of concepts should be based on the emic self-reflection of the tradition carriers: musicians, singers, dancers from traditional groups. (Hood 1960: 55; Merriam 1964: 32.) In ethnomusicology, the emic-etic opposition has been used to emphasise the possibility of approaching a musical culture from two angles: from the inside perspective of the subject (emic) and from the outside perspective of the observer (etic). (Sarv 2000: 46-47.) The terms were created in 1954 by linguist Kenneth Pike, who proposed an emic-etic scale to describe the objectivity of anthropological research. The dichotomy derived originally from the linguistic terms phonemic (>emic), which is the transcription the components of meaningful speech, and phonetic (>etic), which is the transcription the elements of speech sounds. (Pike 1967: 41-42.) Pike's approach was adapted into music research by Finnish ethnomusicologist Erkki Pekkilä in 1980s. (Pekkilä 1988: 36.)

The American folklorist Dan Ben-Amos stressed that emic genre terms should be studied in the context of one tradition community or even tradition carrier (Ben-Amos 1992: 22). The Finnish folklorist Lauri Honko agrees that it is important to study culture-specific categories in informants' own terms but adds that researchers need an agreed analytical vocabulary that enables them to discuss and compare different cultural cases in the system of first and secondary life of folklore, authentic and unauthentic tradition. (Honko 1998: 25, 29.)

The term authentic generally carries the meaning of being genuine, authoritative and respectable, having the quality of realness and credibility, and is a metaphor for non-modern culture. (Hill \& Bithell 2014: 19-24; Bendix 1997: 7.) Folklorists and ethnomusicologists of the 19th century and the first half of the 2oth century approached the term authentic as a national, traditional and rural ideal phenomenon. (Herder 1778-1779; Sharp 1907.) In the context of the classical discipline of folklore, authenticity was a central claim: folklorists admired traditional communities and their values such as orality, "purity" and "non-modernity". (Anttonen 2005; Bendix 1997; Honko 1990; Haapoja 2017: 67.)

The 1970s brought the criticism towards this researcher-oriented thinking. Instead of the academic view that saw national cultures as something pure, 
the focus was suggested to shift to the 'real nature' of contemporary cultures which helps to get a more objective and relevant understanding of features of tradition. (Martins 1974; 276; Wimmer \& Glick 2003: 576.) In this research, the term authentic is understood as a tradition-based living culture that is learned through experience and practised naturally in everyday life.

The Finnish ethnomusicologist Vesa Kurkela interprets the term authentic as a scholarly constructed idealized value. Kurkela investigated how the definition of folk music has been connected with the development of the intellectual idea of nationality and with the discourse of "purity" of traditional culture. According to him, authenticity of folk music could be considered as one of the general myths of musical folklorism. A theoretically constructed binary opposition on an authentic-inauthentic scale doesn't correlate to the natural character of culture. (Kurkela 1989: 339-343.) The 21st century folk music research has adopted the idea of performer-orientated genuineness. One of the criterions of authenticity has been the creative process, understood as musician's personal expression using traditional material as a source. (Hill 2014: 413; cp. Haapoja 2017.)

Usually the terminology and description of the values of music are not taken directly from traditional musicians but rather from intellectuals who observe the music from a distance. For example, the traditional singers in Estonian villages described their old songs to folklore collectors with words like leelo (chant), toon (tone), mõnu (joy) etc., although these folk etymologies were not accepted in the academic discourse. (Rüütel 2004 \& 2005.) Instead, Estophiles and scholars in the middle of the 19th century created the Estonian term regilaul (runic song, Finnish runolaulu, kalevalainen laulu), which denotes the old alliterative folk song of the Finnic nations. Rege- or rigenlied was borrowed into Estonian from the Low German dialect used by Baltic Germans and meant 'folk or dance song' (EES 2012; ss A 2000: 63). In contrast, folk music scholars in Finland started to use rekilaulu to refer to newer end-rhymed stanzaic Finnish folksong. The term rekilaulu is considered to be a loan from the Estonian language, a derivation of the word regilaul (runic song). (Asplund 2006a: 147-148; Kallio \& Frog \& Sarv 2017: 148.)

However, in some cases non-academic music communities succeeded to influence the ethnomusicological vocabulary. For example, since the start of 1990 s the new Estonian term pärimusmuusika (traditional music, literally 'heritage music') has emerged in Estonian folk music circles instead of the term 
rahvamuusika (folk music). As there was a lack of a relevant Estonian translation for the English term traditional music, and also for newer fusional folk music styles, the Estonian composer Valter Ojakäär proposed the terms pärimuslaul and pärimusviis (traditional or heritage song, melody). This terminological suggestion was soon positively adopted by musicians and developed spontaneously into the derivation pärimusmuusika. (Särg \& Johanson 2011: 124.)

The English term traditional music is in the general academic context understood as the music of a group of people who practice traditional culture in which modern technology is rather absent and traditional knowledge plays an important role in everyday life. Music is based on the shared experiences of group members so that singing and playing is spread mainly through joint music making. (Särg \& Johanson 2011: 137.)

The Estonian term pärimusmuusika expanded this understanding significantly. It gave the possibility to speak at the same time about folk music traditions and new professional versions, both of which can be inherited from community members. The concept covers traditional music, the outdated term folk music and comprises the features of world music. It is used to mean both old rural music styles and their modern adaptations to emphasise the continuity of local music tradition. The new term stressed opposition between conservative and progressive attitude to music. Instead of punctilious imitation of old sound recordings and archived transcriptions young musicians tried to capture an internal authenticity and an intuitive (re)creation of ethnic music. This grassrootsorigin term was taken up by the wider folk music revival which started in Estonia in the 1990s. (Särg \& Johanson 2011: 138.)

The Finnish term nykykansanmusiikki (contemporary folk music) first appeared in Finnish media in 1979 in relation to the European Broadcasting Union International Folk Music Festival. (Heikkilä \& Virtanen 2011: 7-8.) The term became accepted in common language in the late 1980s and early 1990s. It primarily referred to a new folk music based style that gained popularity in Europe, America and also Finland, especially among young urban people. (Anttonen 1982: 59.)

Nykykansanmusiikki has significant overlap with the Estonian traditionalmusic-based term pärimusmuusika, but the essence of this Finnish music style is more of a combination of traditional, world and composed music. 
Nykykansanmusiikki is characterised by a desire to break the traditional rules and to find a modern and personal musical expression. (Asplund 2006b: 522523.) During past decades, nykykansananmusiikki has referred specifically to professional music making, characterized by fusion with other styles of music, innovative instrumentation, re-making of traditional tunes, own compositions, and concert forms borrowed from art and popular music practise. (Suutari 2011; Hill 2014; Haapoja 2017: 13-14.) The term nykykansanmusiikki has been critized by both scholars and musicians of Finland due to its ambiguity (Laitinen 1991: 64; Haapoja 2017: 17).

The term world music was created by American ethnomusicologist Robert E. Brown, who founded the ethnomusicology program at the Wesleyan University in Connecticut in the early 1960s. (Williams 2005.) The term came into wider use in the 1980 os for music marketing purposes within media and the music industries, and the term is generally used to classify any kind of non-Western music. The term is also used as a classification of music that combines Western popular music styles with genres of non-Western music that were previously described as folk or ethnic music. (Pegg 2001: 68; Haapoja 2017: 16.)

World music is not an exclusively traditional-music-based style. It may refer to the classical musical forms of various regions of the world, and to modern, cutting-edge pop music styles as well. Since the 1980s, the terms world beat and roots music have been used as synonyms of world music as well. (World Music 2019; Brusila 2003.) World music as a term affected the creation of the Finnish maailmanmusiikki and the Estonian maailmamuusika, both of which are straight translations from English, transmitting the meaning directly from the original language.

Fusion is a musical style that combines two or more genres. For example, rock and roll originally developed from blues, gospel and country music. In this article, fusion music is considered a style in which traditional music has mixed with contemporary Western popular music styles. Some results of this process are the folk pop, folk rock, and folk jazz ensembles that enrich the musical picture at folk festivals. In the discourse of ethnomusicology, the terms global, urban and even rootles folk music are also used. (Thompson 2011.) 


\section{Fieldwork material from Kaustinen and Viljandi}

The material of this research was collected at two folk festivals: the Kaustinen Folk Music Festival (Kaustisen kansanmusiikkijuhlat) in Finland and the Viljandi Folk Music Festival (Viljandi pärimusmuusikafestival) in Estonia during the 20042018 period. The importance of these two events is approximately equal within their own cultural and geographical regions. Kaustinen is one of Scandinavia's largest folk festivals, while Viljandi is the Baltic's largest. The musical styles of the festivals are traditional music and traditional music fusions: folk pop, folk rock, folk jazz etc.

The Kaustinen Folk Music Festival started in 1968 in Kaustinen county in Western Finland (Laitinen 1977). Today the duration of the festival is seven days and it takes place in the second week of July. In recent years the number of performers has been ca. 400o. Audience numbers have been ca. 48 ooo (43 ooo in 2016, 55 o0o in 2017, and 47 o0o in 2018.) (Kluukeri 2018; Kaustisen kansanmusiikkijuhlat 2019.) The Viljandi Folk Music Festival was established in 1993 in the Southern Estonian town of Viljandi. The festival has been fixed for four days in the last weekend of July. The number of singers and musicians has recently been ca. 800 (Zõbin 2018) and the audience number ca. 26000 (25 ooo in 2016, 28500 in 2017, and 26000 in 2018). (Palgi 2017; Paju 2018; Viljandi pärimusmuusikafestival 2019.)

The research material from the Kaustinen and Viljandi festivals was collected systematically since 2004 by the author. The sound and video recordings on the festival field were recorded between 2004 and 2018 especially concentrating on spontaneous singing situations. Within this fieldwork period, ten structured and thematically large interviews were carried out with the organisers, musicians and audience members at both festivals. Since $2007 \mathrm{ca}$. 800 media responses (newspaper and web articles, television and radio broadcasts) have been collected into an electronic database. The festival fieldwork archive also comprises of festival booklets, concert programs, event flyers, newspaper articles and CDS. The collected material is archived in the Estonian Folklore Archives in Tartu.

The structured interviews are an essential part of the research material. There were six group conversations with the Viljandi festival organisers, musicians and audience members, and four with the same group at the Kaustinen festival. 
Informants were chosen among people who had participated in the festivals for at least five years. Interviews consisted of 1o topics comprising all together 30 questions covering the areas of the festivals' historical, artistic, financial and social development, and the influence on the folk music movements and cultural lives of the respective countries. Topics for discussion were: 1 . the historical period and its influence on the festival's inception; 2. the emergence of the idea of the festival; 3 . the concept and content of the festival; 4 . the influence of professional musical education on folk music festivals; 5 . definition and description of the musical style of the festival; 6 . musical changes during the development of the festival; 7. economic strategies and financial survival; 8. formation of the festival team; 9. the internal and public image of the festival; 10. cooperation with other festivals and international festival organisations.

In the next pages I present a comparative analysis of the Kaustinen and Viljandi festivals made on the basis of structured interviews ${ }^{1}$ and collected field work materials. The analysis has been arranged by following the stages of the festivals' history.

\section{The formation of the festivals}

Folk music was a marginal style of music in the general cultural picture of the 1960 s in Finland and the 1980s in Estonia. In both countries mainstream opinion about traditional music tended to be associated with a culturally and economically obsolete village community:

Folk music was so marginal in the 1960s in Finland. You couldn't hear it anywhere. The hardest thing was that folk music was not appreciated. It was not appreciated as much as the jazz that has already become popular alongside classical music. Jazz was already higher music. Folk music was not. This

1 Original interviews were done in Estonian and Finnish languages, the text examples are translated to English. Informants are marked with codes. Numbered list of interviews are enclosed at the end of an article. 
gradually provoked such kind of good protest among those for whom folk music was a normal way of life. (H10 2005)

In the 1960s and 1970s Finland saw a wider rise of the folk music movement. One of the factors highlighting traditional culture and, through this, traditional music was frustration with urbanisation and commerce. One of the aims of the folk music movement became preserving and promoting the lifestyle of the countryside. (Laitinen 2003: 219.) Kaustinen was a traditional village region where the living tradition of violin playing was still viable. Several famous families of violinists confirmed this. The repertoire of local folk group Purppuripelimannit, the flagship of the traditional instrumental music of the Kaustinen county, began to be played more and more on the Finnish radio, and the number of young violinists playing in traditional styles increased significantly.

The Kaustinen Folk Music Festival was established in Finland's Central Ostrobothnia region in the Kaustinen parish in 1968 by local musicians. In the first year, the number of performers and participants was a more than 20000 . The Kaustinen festival gained increasing attention, and it began to serve the revival purposes as well. Therefore, in the early years of the festival the focus was mainly on traditional local folk music from the end of the 19th and start of the 20th century. (Määttälä 2005; Saha \& Westerholm 1987.)

In the late 1980 s Estonians began to look for alternatives to Soviet-era village cappella culture. A social need for ethnically genuine self-expression emerged as well. For example, folk dance evenings with live music - following the Hungarian Táncház movement example -gained popularity in Estonia as well:

\footnotetext{
Opening up and looking for one's own culture began in the late 1980s. By that time, Estonians knew Leegajus, Hellero and Kukerpillid. The dance club movement had already begun. It was influenced by the Leegajus visits to
} Hungary at that time. ( $\mathrm{H}_{5}$ 2004)

One of the places where revival ideas became more vivid was the Southern Estonian town of Viljandi. One of the main prerequisites for this was the active work of the folk music department established in 1989 in Viljandi Culture College (renamed Viljandi Culture Academy in 2003). Viljandi became the location 
for the teaching of folk musicians, not because of long and strong traditions in folk culture, but rather as the result of a regional policy that favoured the establishment of vocational schools in smaller towns and centers to promote the cultural and economic lives of these regions.

The first tutors of the college were several top musicians and folk music experts from Finland and elsewhere in Scandinavia. Over the years, the professionals have provided a significant number of workshops and camps for people with an interest in folk music training. This created enthusiast circles and introduced the idea of a 'native musical language' to ordinary people whose family tradition had been interrupted.

In the early years we had an incredible opportunity to just get a lot of good teachers from abroad, for example from the Sibelius Academy in Helsinki. Anneli Kont-Rahtola brought new winds from the Sibelius Academy. And Kurt Lindblad became a flute and bagpipes teacher at Viljandi Culture College for years. ( $\mathrm{H}_{5}$ 2004)

I think it all started when folk music department was founded in Viljandi and when these people came to study there. The breakthrough came when Anneli Kont began teaching at the folk music department. A completely different approach began to be cultivated, particularly subject-centered. In instrument teaching, the focus was on how to play, what I think is the most important issue in folk music. There was quite a lot of improvisation, as it is normal in folk music. It was immensely exciting, and it kindled a lot of people. (H6 2004)

The Viljandi Folk Music Festival has been organised since 1993. Initially it was a one-day festival attended by approximately 200 participants. (Kiviberg 2019.) The first volunteer team at the Viljandi event was formed by the students and tutors of the local folk music department. Among them were graduates from the first folk music course at Viljandi Culture College, many of whom are still active at the festival today. During the first two years of the festival, the majority of the performers and audience were from the culture school and from a relatively small circle of folk music lovers. Therefore, at the beginning Viljandi Folk was a party for its own people. 
Enthusiasts of both festivals in Finland and Estonia were encouraged by older popular European festivals. Young musicians from Kaustinen were inspired by the Llangollen Folk Music Festival in Wales in 196os and folk music students and teachers from the Viljandi Culture College received positive impetus from participation at the Falun Folk Music Festival in Sweden in 1991 and 1992:

\footnotetext{
Kaustinen had everything that was needed: the players and the music. But the concrete idea of a festival came from a Welsh folk festival in the 196os. From Llangollen. The Finns got there by accident. Then our people started to gather together. In 1968 we had our own party. (H10 2005)
}

Several things happened together. The idea of the festival began to germinate when Viljandi folk music students were in Falun Folk Music Camp and Festival in 1991 and 1992. In 1993 our own festival happened. (H5 2004)

The new generation of musicians got an example of how to adapt the music culture of their ancestors into a contemporary modern musical life in a moderate and respectful way. The aims of the initiators of both festivals became to raise a new folk-culture-loving generation, support and encourage young folk musicians and organise folk music training for everyone.

One of the ideas of the Viljandi festival team was to provide alternatives to the restricted and inflexible way of playing folk music in village cappellas: learning to play by ear, improvising, getting to know rare folk instruments, and playing together. However, the previous traditions could not be changed overnight. Alongside the rural folkloristic cappellas, the Viljandi festival began to present new musical traditions which, over time, became widely known as pärimusmuusika (traditional music).

Throughout the years, the main message of the Viljandi Folk Music Festival has been the promotion of local traditional music in the spirit of the Hungarian composer and ethnomusicologist Zoltán Kodaly and the Estonian composer Veljo Tormis. One of the ideas has been to return to the 'native musical language' and ancestors' musical traditions: 
The idea of our festival was that it would be one of the highlights of the year where all this people would come together. It was also an opportunity to introduce the subject to people who were not folk music oriented. It is very important that people's nationality is expressed in other features than only language. Veljo Tormis propagates all the time this Zoltán Kodaly's idea that "folk music is the musical language of the nation". I think that is very well said. (H6 2004)

This overlaps with the ideas of their Finnish colleagues. In Finland the driving force behind the Kaustinen festival was the revitalisation of own rural culture, maintaining the well-preserved local folk music tradition and popularising it among contemporary audiences:

\begin{abstract}
Although our festival has always had good music from other countries, the most important thing is our own music, the music from our villages. We always have one theme of the year the folk music from some region of Finland. From there we invite performers and teachers. We will not give up on this, despite the booming of world and author music. (H10 2005)
\end{abstract}

The Kaustinen festival initiated a reunion of folk music enthusiasts. Active music making has led to the need for professional specialisation. Contrary to Viljandi's example, Kaustinen has raised a generation of professional musicians out of amateur circles:

\footnotetext{
Previously people played spontaneously and for fun. But for the purposes of performing on stage the instrumentalists began to practice more and more. And then there were so many concerts that it became a profession. (H10 2005)
}

The establishment of the Folk Music Department of Sibelius Academy in Helsinki in 1983 began to influence professional folk musicians to enter the folk music arena. Following the example of Helsinki, folk music institutions were established elsewhere in Finland as well, for example in Kokkola, Rääkkylä, Kuopio and Seinäjoki. (sıв A 2019.) The knowledge of traditional singing and instrumental playing improved and the range of folk music styles expanded. 
In addition to Kaustinen's well-known violin playing style many older ways of making folk music were revived on the basis of archival material:

\begin{abstract}
When the Sibelius Academy began to provide training for folk musicians in the 1980s, many people wanted to study further. The good thing about education is that people are re-learning old styles, things that have disappeared from memory, but are still in the archives. While in the 196os there were some old men who remembered how were played 40 years ago, there are now hundreds of young people who can play like 200 years ago. A good knowledge of different traditions allows to play folk music in a new way, play it freshly and creatively. After all, real folk music has to keep renewing. (Hio 2005)
\end{abstract}

\title{
Quick development
}

In the 1980s, the Kaustinen festival became a mix of hundreds of concerts, workshops, jam sessions and dance events. The repertoire's kaleidoscope of Finnish and other traditional music styles expanded over time. This was due to the increasing knowledge and respectful use of archival sources. Since the end of the 1990s, Viljandi festival also offered a diverse cultural program including dozens of concerts, workshops, dance evenings, a craft yard, an instrument fair, local food, and more. Over time, folk music fusion performances with classical and rock influences were accepted to the concerts. Still, pop music stars were not included in the festival program.

The Kaustinen festival got a modern and magnificent building, the Folk Art Center, in 1987. All the organisations involved in the festival were gathered there: the Folk Music Institute, the Folk Music Museum, the folk music group Tallari and the ITE Folk Art Center (Kaustisen kansanmusiikkijuhlat 2019). Year-round activities at the Kaustinen Folk Art Center such as the preparations of the festival and folk music performances and workshops, were financed from the profits of the summer festival. These events unfortunately always attract a smaller audience compared to pop culture: 
The fact is that we have to take into account the taste of the audience, the music that is currently favoured in society. Thanks to the big stars, we get decent ticket revenue. With this money we can do a number of very good folk music concerts, which would otherwise be at a loss because of the smaller audience. (H10 2005)

As the first compromise between pop and traditional music, the Finnish singer Katri Helena was invited to perform at Kaustinen in 1997. She had released a folkstyle album entitled "Take Me" ("Vie minut") and her backing group included professional folk musicians who had graduated from the Sibelius Academy Folk Music Department. Since then, entertainment and pop concerts have been offered to the audience during the festival.

Kaustinen strived to follow the principle of 'something for everyone'. Folk music courses played an important role in the festival. Music and dance workshops were usually free, although these were also funded by the entertainment events that attract larger numbers of ticket buyers. Thus, contemporary pop music has found its place in the Kaustinen festival program. Despite compromises, the festival, due to its size and reputation, has been able to maintain its role in introducing and popularising folk music in Finland.

As a result of the popularity both at home and abroad, the Viljandi festival was recognised by the city of Viljandi in the end of the 1990s as a top event of local culture. Getting financial and material support for the festival became easier. Ticket sales also improved year by year. The increase in resources enabled the development of a festival organisation:

In the beginning we had to stand for our festival, talk and talk and talk everywhere. Now the city of Viljandi has taken us as their business card. We are known. (H6 2004)

A lot of festival tickets will be bought already before we have announced the final program. This shows that the festival audience trusts our choices. (H2 2004)

In 2008 the Viljandi Folk Music Festival got the renovated and roomy building, which soon became the well-known Estonian Traditional Music Center. Two institutions were established as well: The August Pulst School that provided 
folk music education for children and adults and The Traditional Music Center Library that included a good folk music library and sound recordings collection. It is significant that in spite of the big and modern house the Viljandi Folk Music Festival has managed to stay self-sufficient. The festival management was open to cooperation with other cultural organisations all over Estonia and the Baltics, and the building became year-round popular place for concerts, theatre and other performing arts. The festival was financed from the profits of Estonian Traditional Music Center.

\section{The festivals today}

Both Kaustinen and Viljandi festivals continuously base their choice of main local and foreign performers on the criterion that musicians must be competent in their own traditional culture. Popular music features are adapted to festival programs to some extent, but all world-music-style collaborations are still expected to be based on a good knowledge of tradition. Awareness of quality of foreign music naturally demands international experience. Both festival organisations participate in various European and other international projects every year.

Kaustinen's main goal has remained in the presentation of local and foreign traditional music cultures. Each year the festival has focused on one Finnish province and one foreign region. An important part of the festival have been the folk music workshops which are free of charge and the joint music-making evenings for music lovers:

In the early 1980s, when I attended the festival for the first time, an important part of it was the common jam sessions around the campfire and wherever.

People played spontaneously together and learned from each other. That was the most important reason for me to come to the festival. It offered so much more than just going to concerts. Such jam sessions have now decreased.

However, it is understandable. Folk musicians have become professional and have jam sessions on stage. (H10 2005) 
Kaustinen has influenced the emergence of professional folk musicians. Thanks to the rise and valuation of professionalism, the reputation of Finnish folk music and thus of Finnish traditional culture has increased in society.

The main goal of the Viljandi festival has so far been to introduce and teach Estonians about their folk music and culture, to give people back their 'musical mother tongue' and to make traditional music an active part of their everyday lives. The audience is also given the opportunity to get to know other music traditions through recognised foreign performers.

The educational principles of the festival are well established. We know what we want say and show to the audience. The main thing is to get our traditional music closer to people. (H6 2004)

The popularity of the Viljandi Folk Music Festival has facilitated the acceptance and inclusion of folk music in general education as well as music schools:

Our graduates of the Viljandi Culture Academy have now been employed in several music schools. This is how the idea of traditional musical culture spreads. Viljandi Folk Festival's Estonian ETNo camp for young musicians has become extremely popular. Not everyone needs to become professionals. The main thing is, that people would enjoy their singing and playing and would not be ashamed it. (H6 2004)

The style and face of the festival can change significantly only with a new generation. And we ourselves have to grow these people up in our community. ( $\mathrm{H}_{5}$ 2004)

The spread of folk music as a hobby has also increased the reputation of folk culture. The folk music events are crossing the news threshold more often than in the early years of festival: 
Browsing through the newspapers was certainly part of the organisation of the festival. Was there anything written about us and was it written well? At some point this need was subsided when you saw that the feedback was superficial.

There were no good in-depth articles. This situation has changed now. (H1 2004)

\section{Terminology of festivals}

One sub-topic of the festival questionnaire was related to definitions. I was interested in how people would define and describe the musical style of their festival. The hours of open and active discussion with festival associated interviewees raised some new and topical themes in addition to the prepared ones. As a supplement to the expected explanations I got a bonus topic: the emergence of new terminology.

The organisers of the Viljandi Folk Music Festival stressed that they wanted to be in opposition to the outdated term rahvamuusika (folk music) as the word was connected with conservative folkloristic performances made by village folk ensembles during the Soviet period. Since the 1950s, amateur bands in local culture houses played music exactly as it had been preserved in the archives. Normal improvisation and variation in traditional pieces were considered mistakes. The whole group, even the players of simple percussion instruments, always performed from a musical score:

\footnotetext{
So, why didn't we want to use the term folk music? Because today it's not

folk's music anymore. It doesn't belong to the people. It's like a museum piece...

Pärimusmuusika is living music that has a natural life and is handed over from person to person. (H6 2004)
}

According to Viljandi festival organisers the Estonian word pärimusmuusika can be defined as living folk music. They described it as improvisational and creative traditional music. Interviewees remembered that the word pärimusmuusika was found and immediately adopted from an LP by popular Estonian folk and country 
band Kukerpillid in 1988. The band collected its folk repertoire by visiting old traditional singers and instrument players all over Estonia, especially on Kihnu island, which is now on the UNEsco World Heritage list. Kukerpillid embodied an attitude of living folk music that was perfect for erstwhile young musicians from Viljandi:

I think the band Kukerpillid had a biggest influence of general accepting the concept of 'traditional music' instead of 'folk music'. The word pärimusmuusika came from their LP. ( $\mathrm{H}_{5}$ 2004.)

However, one of the musical advisers for the band was composer Valter Ojakäär, who influenced the birth of the name of this musical genre. The term pärimusmuusika has come into wider use in relation to the Viljandi Folk Music Festival, especially because of its Estonian name Viljandi pärimusmuusikafestival. Somehow the phrase 'folk music' has been used in the festival's English name, which the organisers explained as an international tradition of festival names.

The Kaustinen Folk Music Festival's organisers and performers argued about the terms world music (maailmanmusiikki) and fusion music (fuusiomusiikki). They admitted that the audience demands for more world music, despite the fact that people do not actually know the meaning of the word or content of this phenomenon:

At the end of the 1980s people suddenly started to talk about a style called world music. This phenomenon came to us in only a few years and this influenced Finnish musicians a lot. They started to play music from other counties with local Finnish instruments and their own music with strange instruments. It was ridiculous that all Finnish bands needed to have the Australian aborigine didgeridoo. There was a joke: What do ordinary people consider to be world music? This is a rock band where one of the members sings in a lesser known exotic language and another plays an instrument made from a dead animal, for example the bagpipes. And that is folk music? Same as previous, but without rock. In my opinion world music requires well-balanced cooperation between different musical cultures. (H10 2004) 
According to several interviewees, the real essence of world music is a balanced and delicate combination of different musical traditions. The Kaustinen festival team was also unsatisfied with the vague terminology that was forced on them from outside. Inside the festival community there was a clear understanding of what world music is and how it could be adapted to the local context. The interviews showed that there is a need for a new clear definition.

Whilst the interviewed Estonians were satisfied with the word pärimusmuusika, which had extended the meaning of traditional music, the Finns needed a more specific and concrete term. The Finnish word nykykansanmusiikki (contemporary folk music) seemed no longer to satisfy the festival team because it had become too general and all-inclusive. However, during conversations with the Finnish interviewees the phrase Finnish world music (suomalainen maailmanmusiikki) appeared. It has been explained as a compound of ancient traditional music and contemporary musical styles in a Finnish mode. This is in principle the same expression that ethnomusicologist Juniper Hill noticed being used among Finnish contemporary folk musicians during at the start of the 21st century: world music from Finland (Hill 2007: 50).

\section{Conclusion}

The Kaustinen Folk Music Festival in Finland and the Viljandi Folk Music Festival in Estonia can be considered as similar phenomena. The ethnomusicological fieldwork that was done in both festivals during 2004-2018 confirms that the events' main goal is to restore the value of traditional music and present it in a language that speaks to today's listener. Music that has accompanied people for countless generations is being seen as part of a holistic and sustainable national culture. However, the festivals, which began on opposite shores of the Finnish gulf developed in different ways. Kaustinen has gradually moved from country to city - amateur musicians have become professional performers. Viljandi has turned from city to countryside - professional folk musicians have revived the folk music hobby across the country.

The Kaustinen festival started in an area where the local folk music tradition was viable. Folk violin playing has been consistently popular in Central 
Ostrobothnia. Amateur folk musicians still present their ancestors' valuable repertoire, learn and teach music by ear, and vary melodies according to their experience and cognition. At the same time, the repertoire of trained folk musicians is historically broader because of the knowledge of temporal styles learned from archives. Both ways of playing folk music now meet in Kaustinen supplementing and influencing each other.

Unlike Kaustinen, the initiators of the Viljandi festival were professional musicians who became acquainted with folk music mainly through archives and folklore studies. As a result of the festival the practice of folk culture has intensified, for example as seen in the dance club movement, whose big reunion dance parties were on the festival's free stage. In addition, singing folk songs, building folk instruments and making national handicrafts have become more popular as well. During the festival days several concerts are organised outside Viljandi in smaller centres and villages. In this way the Viljandi festival has constantly and successfully spread throughout Estonia a new folk-music-related mentality, including the definition pärimusmuusika.

The Estonian word rahvamuusika (folk music), meaning traditional Estonian peasant music originating from the ancient Finnic culture, was coined around 1900 by local scholars. The pärimusmuusika was born in the end of the 2oth century in music communities, and it covers different traditional and fusion music styles. An example of the development of this term could encourage researchers to observe and take into consideration the points of view of tradition-related societies: active musicians and students, amateurs and music lovers, festival organisers and participants.

The terminological development is a continual process. Field work interviews conducted with people related to the Kaustinen Folk Music Festival in Finland and Viljandi Folk Music Festival in Estonia showed that there is a need for new emic synonyms for current music styles. Thematic discussions highlighted opposition between the over-exploited Finnish term nykykansanmusiikki and its contemporary and more relevant parallel suomalainen maailmanmusiikki.

The active role of folk music festivals tends to generate new musical genres and therefore creates a constant demand for new vocabulary. Fieldwork material collected from Estonia's and Finland's largest folk music festivals over the last 15 years indicated that there is a potential to create relevant ethnomusicological 
terminology that could be not constructed by scholars but rather is created naturally by the real holders of contemporary folk music.

\section{Acknowledgements}

This research was supported by research project "Folklore in the Process of Cultural Communication: Ideologies and Communities" IUT 22-4 (Estonian Ministry of Education and Research, Estonian Research Council), by the Center of Excellence in Estonian Studies (CEEs, European Regional Development Fund), and the University of Tampere, Doctoral Programme of Communication, Media and Theatre, Sub-programme of Music Studies.

\section{References}

\section{Literature}

Anttonen, Pertti (1982) "Kansanmusiikkia - elävänä tai kuolleena". Suomalainen vuosikirja 1983. Ed. Honko, Lauri. Helsinki: Suomalaisen Kirjallisuuden Seura, 46-6o.

Anttonen, Pertti (2005) Tradition through Modernity. Postmodernism and the Nation-State in

Folklore Scholarship. Studia Fennica Folkloristica 15. Helsinki: Suomalaisen Kirjallisuuden

Seura. https:/ / doi.org/10.21435/sff.15

Asplund, Anneli (2006a) "Runolaulusta rekilauluun: Kansanlaulun murros". Suomen musiikin historia: Kansanmusiikki. Eds. Päivi Kerola-Innala et al. Helsinki: Werner Söderström ox, 108159.

Asplund, Anneli (2006b) "Kansanmusiikin paluu". Suomen musiikin historia. Kansanmusiikki. Eds.

Päivi Kerola-Innala etc. Helsinki: wsoy, 506-523.

Ben-Amos, Dan (1992) Do We Need Ideal Types (in Folkore)?: An Address to Lauri

Honko. Nordic Institute of Folklore. Papers No. 2. Turku: Nordic Institute of Folklore.

Bendix, Regina (1997) In Search of Authenticity. The Formation of Folklore Studies.

Madison, Wisconsin: The University of Wisconsin Press. 
Brusila, Johannes (2003) 'Local Music, Not from Here'. The Discourse of World Music Examined through Three Zimbabwean Case Studies: The Bhundu Boys, Virginia Mukwesha and Sunduza. Finnish Society for Ethnomusicology Publications 10. Helsinki: Finnish Society for Ethnomusicology.

Dundes, Alan (1980) Interpreting Folklore. Bloomington: Indiana University Press. EES (2012) Eesti etümoloogiasõnaraamat. Eds. Iris Metsmägi, Meeli Sedrik \& Sven-Erik Soosaar. Eesti Keele Instituut. Tallinn: Eesti Keele Sihtasutus. https: / www.eki.ee/dict/ety/ index.cgi?Q=regi-\&F=M\&Co6=et (visited 27.07.2019).

Falassi, Alessandro (1987) "Festival: definition and morphology". Time Out of Time: essays on the festival. Albuquerque, usA: University of New Mexico Press, 1-10.

Haapoja, Heidi (2017) Ennen saatuja sanoja: menneisyys, nykyisyys ja kalevalamittainen runolaulu nykykansanmusiikin kentällä. Suomen Etnomusikologisen Seuran julkaisuja 22. Helsinki: Helsingin yliopisto \& Suomen Etnomusikologinen Seura. http://julkaisut.etnomusikologia.fi/julkaisut/Haapoja_Heidi_Ennen_Saatuja_Sanoja_2017. pdf (visited 10.10.2019).

Heikkilä, Johannes \& Virtanen, Hannu (eds.) (2011) Pilven piirtä myöten. Suomietnon synty. Helsinki: Suomalaisen Kirjallisuuden Seura.

Herder, Johann Gottfried (1778-1779) Volkslieder. Weygand, Leipzig. http:/ / www.zeno.org/Lesesaal/N/9781482559576?page=2 (visited 20.03 2019).

Hill, Juniper (2007) "Global Folk Music' Fusions: The Reification of Transnational Relationships and the Ethics of Cross-Cultural Appropriations in Finnish Contemporary Folk Music". Yearbook for Traditional Music 39, 50-83.

Hill, Juniper (2014) "Innovation and Cultural Activism through the Re-imagined Pasts of Finnish Music Revivals". The Oxford Handbook of Music Revival. Eds. Caroline Bithell \& Juniper Hill. Oxford University Press, 393-417. https:/ / doi.org/10.1093/ oxfordhb/9780199765034.013.008

Hill, Juniper \& Bithell, Caroline (2014) "An Introduction to Music Revival as Concept, Cultural Process, and Medium of Change". The Oxford Handbook of Music Revival. Eds. Caroline Bithell \& Juniper Hill. Oxford University Press, 3-42.

Honko, Lauri (1998) Textualising the Siri Epic. Folklore Fellows' Communications 264. Helsinki: Academia Scientiarum Fennica.

Honko, Lauri (1990) "Folkloreprosessi". Sananjalka 32, Helsinki, 93-121.

Hood, Mantle (1960) "The Challenge of Bi-Musicality". Ethnomusicology 4, 55-59. https:/ / doi. org/10.2307/924263 
ICтм (2019) "Statutes of the International Council for Traditional Music International Council for Traditional Music". A Non-Governmental Organization in Formal Consultative Relations with UNESCO. http://ictmusic.org/statutes-ictm (visited 20.03.2019).

JIFMC (1955) "Definition of Folk Music. Plenary session. Resolutions". Journal of the International Folk Music Council 7. The International Folk Music Council, 23. https:/ / doi. org/10.2307/834527

Jordan, Jenie (2016) "Focus on Finnish Festivals". Festivaalien Suomi. Ed. Satu

Silvanto. Cuporen julkaisuja 29. Helsinki: Kulttuuripoliittisen tutkimuksen edistämissäätiö, 212217.

Kainulainen, Kimmo (2005) Kunta ja kulttuurin talous. Tulkintoja kulttuuripääoman ja festivaalien aluetaloudellisista merkityksistä. Tampere: Tampere University Press. https:/ / tampub.uta.fi/bitstream/handle/10024/67538/951-44-6439-7.pdf?sequence=1 (visited 20.03.2019).

Kaustisen kansanmusiikkijuhlat (2019) Kaustinen Folk Music Festival. Webpage of the festival. https:/ / kaustinen.net (visited 15.08.2019).

Kallio, Kati; Frog; Sarv, Mari (2017) "What to Call the Poetic Form - Kalevala-Meter or Kalevalaic Verse, regivärss, Runosong, the Finnic Tetrameter, Finnic Alliterative Verse or Something Else?". The Retrospective Methods Network Newsletter 12-13, 139-161. https:/ / biblio.ugent.be/publication/7167447/ file/8541094.pdf (visited 24.07.2019).

Karpeles, Maud (1967) Cecil Sharp: His Life and Work. The University of Chicago press. https:/ / archive.org/details/cecilsharphislifookarp/page/n5 (visited 20.03.2019).

Keegan-Phipps, Simon \& Winter, Trish (2014) "Contemporary English Folk Music and the Folk Industry". The Oxford Handbook of Music Revival. Eds. Caroline Bithell \& Juniper Hill. Oxford University Press, 489-509. https:/ /doi.org/10.1093/oxfordhb/9780199765034.013.003

Kiviberg, Ando (2019) "Festival tuli, et jääda!". Ajalugu. Viljandi Folk Music Festival. https:/ / www.viljandifolk.ee/festivalist/ajalugu (visited 15.08.2019)

Kluukeri, Iina (2018) "Kaustisen kansanmusiikkijuhlien vetovoima jatkuu - festivaalit veti runsaan yleisön, yli 47 ooo kävijää". Yle uutiset, 16.07.2018. https://yle.fi/uutiset/3-10306501 (visited 31.05.2019).

Kurkela, Vesa (1989) Musiikkifolklorismi ja järjestökulttuuri: kansanmusiikin ideologinen ja taiteellinen hyödyntäminen suomalaisissa musiikki- ja nuorisojärjestöissä. Suomen etnomusikologisen seuran julkaisuja 3. Jyväskylä. 
Kuutma, Kristin (1998) "Festival as Communicative Performance and Celebration of Ethnicity". Folklore. Electronic Journal of Folklore 7, 12-26. http:/ / www.folklore.ee/folklore/vol7/festiva. htm (visited 15.08.2019).

Kõmmus, Helen (2007)"Viljandin kansanmusiikkifestivaalin runolauluesitysten reseptio

Viron kirjoittavassa mediassa 2000-2006". Etnomusikologian vuosikirja 19, 198-205.

Laitinen, Heikki (1977). "Kaustislaisuuden" synty. Kaustisen ensimmäiset kansanmusiikkijuhlat ja maaseutukulttuurin paluu 196o-luvun lopun Suomessa. Käsikirjoitus. Tampereen yliopisto.

Laitinen, Heikki (1987) "Kaksikymmentä kertaa Kaustinen". Kansanmusiikki 2, 3-69.

Laitinen, Heikki (1991) "Oma perinne vieraana kulttuurina: 180o-luvun suomalainen kansanmusiikki tutkimuksen kohteena". Kansanmusiikin tutkimus. Metodologian opas. Sibelius-Akatemian julkaisuja 4. Ed. Pirkko Moisala. Helsinki: vAPK, 59-85.

Laitinen, Heikki (2003 [1989]) "Suomalaisen kansanmusiikkiliikkeen taustasta ja luonteesta". Iski sieluihin salama. Kirjoituksia musiikista. Eds. Hannu Tolvanen, Riitta-Liisa Joutsenlahti. Helsinki: Suomalaisen Kirjallisuuden Seura, 217-223.

Livingston, Tamara (1999) "Music Revivals: Towards a General Theory". Ethnomusicology 43:1, 66-85. https://doi.org/10.2307/852694

Martins, Herminio (1974)."Time and Theory in Sociology". Approaches to Sociology. An Introduction to Major Trends in British Sociology. Ed. J. Rex. London and Boston: Routledge \& Kegan Paul, 246-294.

Merriam, Allan P. (1964) The Anthropology of Music. Evanston, Illinois: Northwestern University Press.

Määttälä, Viljo S. (2005) Kaustisella kivetkin soi. Toimintaa ja tapahtumia festivaalivuosien varrelta 1968-2002. Kansanmusiikki-instituutin julkaisuja 57. Kaustinen: Kansanmusiikki-instituutti.

Nettl, Bruno (2010) Nettl's Elephant: On the History of Ethnomusicology. Urbana: University of Illinois Press.

Paju, Keit (2018) "Viljandi pärimusmuusika festivali külastas 26 ooo inimest". Õhtuleht, 30.07.2018. https:/ / www.ohtuleht.ee/889618/viljandi-parimusmuusika-festivali-kulastas26-ooo-inimest (visited 31.05.2019).

Palgi, Greete (2017) "Suurenenud piletimüük ja abi ministeeriumidelt aitavad juubelifolki meelde jätta". Sakala, 1.08.2017 (visited 31.05.2019).

Pegg, Carole (2001) "Folk Music". The New Grove Dictionary of Music and Musicians. Second edition. Volume 9. Ed. Stanley Sadie. London, New York: Macmillan Publisher, 64-68. https://doi.org/10.1093/gmo/9781561592630.article.09933 
Pekkilä, Erkki (1988) Musiikki tekstinä. Kuulovaraisen musiikkikulttuurin analyysiteoria ja -metodi. Suomen Musiikkitieteellinen Seura. Acta Musicologia Fennica 17. Jyväskylä.

Peirce, Charles (2001) "Mikä merkki on?". Ajatus 58, 9-19.

Pike, Kenneth (1967) Language in Relation to a Unified Theory of the Structure of Human Behavior. 2nd edition. The Hague: Mouton. https:/ / doi.org/10.1037/14786-000

Ramnarine, Tina K. (2003) Ilmatar's inspirations: nationalism, globalization, and the changing soundscapes of Finnish folk music. Chicago and London: The University of Chicago Press.

Rantanen, Saijaleena (2013) "Laulu- ja soittojuhlat suomalaisen kansakunnan rakentajina 180o-luvun lopulla". Musiikki 3-4/2013, 61-84.

Rantanen, Saijaleena (2016) "Musiikkifestivaalien alkuvaiheet Suomessa: Kansanvalistusseuran laulu- ja soittojuhlat $1800-l u v u n$ lopulla". Festivaalien Suomi. Ed. Satu Silvanto. Cuporen julkaisuja 29. Helsinki: Kulttuuripoliittisen tutkimuksen edistämissäätiö, 18-25.

Rüütel, Ingrid (1999) "Folk Song as a Musical Mother Tongue in Modern Society". Music and Nationalism. The Finnish Kodály Center Yearbook 1998-99. Eds. Matti Vainio \& Jouko Laaksamo. University of Jyväskylä. Department of Musicology. Jyväskylä, 25-39.

Rüütel, Ingrid (2004) "Kansanlaulu alueellisen ja kansallisen identiteetin muokkaajana ja ilmentäjänä Virossa". Kenen kotiseutu. Näkökulmia kotiseutukeskusteluun. Kotiseutupäivät Tampereella 30.7--3.8.2003. Eds. Lassi Saaressalo ja Erja Helenius. Tampereen museoiden julkaisuja 72. Tampere: Tampereen Museo, 51-56.

Rüütel, Ingrid \& Tiit, Ene-Margit (2005) Pärimuskultuur Eestis - kellele ja milleks, I. Eesti Kirjandusmuuseumi etnomusikoloogia osakond. Ed. Kanni Labi. Tartu: Tartu Ülikooli kirjastus.

Saha, Hannu \& Westerholm, Simo (1987) "Oliko Konsta Jylhä iskelmäsäveltäjä?".

Kansanmusiikista populaarimusiikiksi. Aineistoa kansanmusiikin teemavuoden seminaarista 14.15.2.1987. Ed. Ilpo Saunio. Helsinki: Kansanmusiikin keskusliitto, 31-38.

Sarv, Vaike (2000) Setu itkukultuur. Ars Musicae Popularis 14. Tartu, Tampere.

SibA (2019) Sibelius-Akatemia. Esittely. https:/ / www.uniarts.fi/sibelius-akatemia (visited 15.08.2019).

Silvanto, Satu (2016) "Festivaalien merkityksestä: Johdanto Festivaalien Suomi-kirjan teemoihin". Festivaalien Suomi. Helsinki: Cuporen julkaisuja 29. Helsinki: Kulttuuripoliittisen tutkimuksen edistämissäätiö, 8-16.

Sharp, Cecil James (1907) English Folk Song, Some Conclusions. London: Simpkin \& Co etc. https://archive.org/details/englishfolksongsooshar/page/n6 (visited 20.03.2019). 
SSA (2000) Suomen sanojen alkuperä: Etymologinen sanakirja III: R-Ö. Eds. Ulla-Maija Kulonen, Satu Tanner etc. Helsinki: Suomalaisen Kirjallisuuden Seura, Kotimaisten kielten tutkimuskeskus.

Suutari, Pekka (2011) "Petroskoin kansanmusiikkiskene: näkökulma nykypäivän karjalaisuuteen". Laulu kulttuurisena kommunikaationa. Runolaulu-Akatemian julkaisuja 16. Juminkeon julkaisuja 87. Eds. Pekka Huttu-Hiltunen et al. Kuhmo: Juminkeko-säätiö, 63-74.

Särg, Taive \& Johanson, Ants (2011) "Pärimusmuusika mõiste ja kontseptsiooni kujunemine Eestis". Mäetagused. Electronic Journal of Folklore 49, 115-138. https:/ / doi.org/10.7592/ MT2011.49.parimusmuusika

Šmidchens, Guntis (2014) "The Power of Song: Nonviolent National Culture in the Baltic Singing Revolution". New Directions in Scandinavian Studies. Seattle \& London: University of Washington Press; Copenhagen: Museum Tusculanum Press.

Zõbin, Janno (2018) "Rahvustunne, elektroonikatorm ja noored tulevikulootused Viljandi päikese all. Muljeid Viljandi folgilt!". Postimees, 29.07.2018. https:/ / kultuur.postimees. ee/5971411/rahvustunne-elektroonikatorm-ja-noored-tulevikulootused-viljandi-paikese-all (visited 31.05.2019).

Thompson, Tok (2011) "Beatboxing, Mashups, and Cyborg Identity: Folk Music for the TwentyFirst Century". Western Folklore 70:2, 171-193.

Turino, Thomas (1999) "Signs of Imagination, Identity, and Experience: A Peircian Semiotic Theory for Music". Ethnomusicology 43:2, 221-255. https://doi.org/10.2307/852734

Viljandi pärimusmuusikafestival (2019). Viljandi Folk Music Festival. Webpage of the festival. https://viljandifolk.ee (visited 15.08.2019).

Williams, Jack (2005) "Robert E. Brown brought world music to San Diego schools". The San Diego Union-Tribune. https:/ / centerforworldmusic.org/wp-content/uploads/2019/o5/ Robert-E-Brown-Brought-World-Music-to-San-Diego-Schools.pdf (visited 5.10.2019). Wimmer, Andreas \& Glick Schiller, Nina (2003) "Methodological Nationalism, the Social Sciences, and the Study of Migration: An Essay in Historical Epistemology". International Migration Review 37:3, 576-610. https://doi.org/10.1111/j.1747-7379.2003.tboo151.x World Music (2019). Wikipedia. The free encyclopedia. https://en.wikipedia.org/wiki/World_ music (visited 31.05.2019). 


\section{Interviews}

Hi (2004) Tartu, Estonia 28.10.2004. Former organiser of Viljandi Folk Music Festival, supervisor of Viljandi Cultural Academy of Tartu University, musician. Interviewer Helen Kõmmus. HD-recording is in Estonian Folklore Archives in Tartu, Estonia.

H2 (2004) Viljandi, Estonia 2.11.2004. Program manager of Viljandi Folk Music Festival, lector of department of cultural management of Viljandi Cultural Academy of Tartu University, musician. Interviewer Helen Kõmmus. HD-recording is in Estonian Folklore Archives in Tartu, Estonia.

$\mathrm{H}_{3}$ (2004) Viljandi, Estonia 2.11.2004. Organiser of Viljandi Folk Music Festival, employee of Estonian Traditional Music center. Interviewer Helen Kõmmus. HD-recording is in Estonian Folklore Archives in Tartu, Estonia.

$\mathrm{H}_{4}$ (2004) Viljandi, Estonia 2.11.2004. Organiser of Viljandi Folk Music Festival, coordinator of public relations and inner-Estonia cooperation of Viljandi Cultural Academy of Tartu University, musician. Interviewer Helen Kõmmus. HD-recording is in Estonian Folklore Archives in Tartu, Estonia.

$\mathrm{H}_{5}$ (2004) Viljandi, Estonia 2.11.2004. Organiser of Viljandi Folk Music Festival, musician. Interviewer Helen Kõmmus. HD-recording is in Estonian Folklore Archives in Tartu, Estonia. H6 (2004) Tartu, Estonia 6.11.2004. Head of Viljandi Folk Music Festival, supervisor of Viljandi Cultural Academy of Tartu University, musician. Interviewer Helen Kõmmus. HDrecording is in Estonian Folklore Archives in Tartu, Estonia.

$\mathrm{H}_{7}$ (2005) Ikaalinen, Finland 13.03.2005. Organiser of Kaustinen Folk Music Festival, musician. Interviewer Helen Kõmmus. HD-recording is in Estonian Folklore Archives in Tartu, Estonia.

H8 (2005) Ikaalinen, Finland 13.03.2005. Long-term visitor of Kaustinen Folk Music Festival. Interviewer Helen Kõmmus. HD-recording is in Estonian Folklore Archives in Tartu, Estonia.

H9 (2005) Ikaalinen, Finland 13.03.2005. Former organiser of Kaustinen Folk Music Festival, musician, traditional instrument builder. Interviewer Helen Kõmmus. HD-recording is in Estonian Folklore Archives in Tartu, Estonia.

H10 (2005) Kaustinen, Finland 30.04.2005. Program manager and organiser of Kaustinen Folk Music Festival. Interviewer Helen Kõmmus. HD-recording is in Estonian Folklore Archives in Tartu, Estonia. 